\title{
Impact of Fadama I Project on Rural Household Income and Poverty in Goronyo Local Government Area, Sokoto
}

\author{
Muhammad Bashir Mustapha ${ }^{1}$, Balarabe Ibrahim Yusuf ${ }^{2, *}$ \\ ${ }^{1}$ Department of Economics, Shehu Shagari College of Education, Sokoto, Nigeria \\ ${ }^{2}$ Department of Agriculture Science, Shehu Shagari College of Education, Sokoto, Nigeria \\ Email address: \\ bashmm2000@yahoo.com (M. B. Mustapha),balarabebally@gmail.com (B. I. Yusuf) \\ ${ }^{*}$ Corresponding author
}

To cite this article:

Muhammad Bashir Mustapha, Balarabe Ibrahim Yusuf. Impact of Fadama I Project on Rural Household Income and Poverty in Goronyo Local Government Area, Sokoto. International Journal of Agricultural Economics. Vol. 4, No. 6, 2019, pp. $254-258$. doi: $10.11648 /$ j.jiae.20190406.11

Received: October 2, 2019; Accepted: October 14, 2019; Published: October 25, 2019

\begin{abstract}
The study assess the impact of Fadama I project on income and poverty of beneficiaries in Goronyo Local Government area of Sokoto State, Nigeria. A total of 160 respondents were selected using multistage, purposive and random sampling techniques. The data was analysed using descriptive statistics and Foster, Greer and Thobecke (FGT) poverty index. The findings of the study on the demographic characteristics shows that majority of the beneficiaries are aged (55 - 65years) with no formal education. The project beneficiaries expressed satisfaction with the approach and monitoring methods adopted by Fadama I project in the implementation of the objectives, they also opined that the project had increased their incomes and had succeeded in addressing the farming needs of households in the study area. Moreover, the result revealed that Fadama I project beneficiaries had a mean per capita income of $\$ 28,332.86$ before and $\$ 83,364.47$ after Fadama I project intervention. The result of the FGT poverty index indicated that 66 percent of the beneficiaries' households were poor and 34 percent were non-poor before the project intervention. The result revealed that Fadama I project beneficiaries had increased the beneficiaries' mean per capita income from $\$ 28,332.86$ before the project to $\$ 83,364.47$ after the project intervention. The study also revealed that Fadama I project decreased the number of poor beneficiaries from $66 \%$ before to $57 \%$ after the project intervention. The study recommends that Governments and Development partners need to continue to support agriculture through project interventions such as Fadama I project using appropriate strategies that suit the beneficiaries' peculiarities.
\end{abstract}

Keywords: Fadama-project, Impact, Income, Poverty, Beneficiaries, Sokoto State

\section{Introduction}

The problem of poverty in Nigeria and in Sokoto State in particular has not been adequately and critically analyzed, despite various approaches at addressing the challenge. The enormous amount of money spent in attempting to improve the standard of living of Nigerians without success calls for a fundamental review of the past approaches and their impacts to see what lessons can be learned. The percentage of Nigerians living in absolute poverty rose to 60.9 per cent in 2010, compared with 54.7 per cent in 2004 (National Bureau of Statistics [1]. North-West and North-East geopolitical zones recorded the highest poverty rate in Nigeria with 77.7 percent and 76.3 percent respectively, while Sokoto tops the list of poor states with 86.4 per cent [2].

The term Fadama is used to refer to low laying lands subject to seasonal flooding or water logging along the banks of streams or depressions. It is a Hausa word meaning, the seasonally flooded or floodable plains along major savannah rivers and or depressions or adjacent to seasonally or perennially flowing streams and rivers [3]. The National Fadama Development Project (NFDP) is a project of the Federal Government of Nigeria through which the pooled World Bank loan is used to finance the development of Fadama lands via small-scale irrigation in states with Fadama development potentials. Fadama 1 project was an agricultural scheme, which recognized Nigeria as a country blessed with potentially good land and water resources. It aimed at promoting sustainable agricultural development 
through the construction of 50,000 shallow tube wells with a capacity to irrigate about 100,000 hectares (ha) of Fadama Lands in Bauchi, Kano, Sokoto and other eligible states over a period of four (4) years [3]. It was an agricultural development project, with a partnership collaboration between the World Bank and the Federal Government of Nigeria together with three (3) core benefiting states of Bauchi, Kano and Sokoto [4].

Absence of information on projects and policy impact on rural beneficiaries in Nigeria poses a serious problem in evolving an all embracing solution to the problem of poverty. This is due largely to definitional inadequacies, measurement errors, inadequate data, and limited researches [5]. Food and Agriculture Organization [6] observed that many antipoverty and food security policies and projects in Nigeria had failed largely because these policies and projects were conceptualized and formulated using reports of the more robust and influential organizations such as the World Bank, United Nation Development Program (UNDP), United Nation International Children Emergency Fund (UNICEF), etc. National aggregates may not necessarily reflect local peculiarities in structure, extent, pattern and profile [6]. An assessment of the impact of FADAMA I Project on Poverty Reduction will provide a clear picture of what needs to be done to re-strategize and develop an approach that will ensure that better progress is made toward achieving the sustainable Development Goals in Nigeria.

This study is therefore targeted at Fadama I Project in Goronyo Local Government Area of Sokoto State with a view to assessing the perception of the beneficiaries on the project intervention and to assess the project impact on beneficiaries' income and poverty statuses.

\section{Methodology}

The study was conducted at Goronyo Local Government Area of Sokoto State, Nigeria. Goronyo Local Government with a total area of 1,444,368 sq. kilometers comprises of Hausa, Fulani and Bugaje tribes. Farming and fishing are the major occupations of the people of the area a, while millet, sorghum, rice and onion are the main crops cultivated in Goronyo [7]. The leading Irrigation Dam in Sokoto State, is located in the area under study and is one of the major irrigation Dams that contributed greatly in agriculture and fishing [1]. Primary data for the study were collected using structured questionnaire while secondary data were sourced from text books, journals, and other relevant materials. The sampling method used is multistage-sampling technique. Goronyo and Shinaka Districts in Goronyo Local Government Area were purposively selected, out of which 5 villages were randomly selected from each of the Districts. A total of 160 beneficiaries were drawn, 16 beneficiaries from each village, using simple random sampling procedure. Descriptive statistics (means, frequency, percentages) and Foster, Greer and Thobecke (FGT) poverty index measure were used to analyze the data. Poverty line was determined using the $\$ 1.25$ and $\$ 1.5$ to establish the poverty status of core poor, moderately poor and non poor before and after the intervention programs. The Foster, Greer and Thobecke [8] weighted poverty index was used to determine the poverty profile of the beneficiaries. The FGT measure for the ith group $\left(\mathrm{P}_{\mathrm{a}}\right)$ is specified as:

$$
\mathrm{P}_{\alpha}=\mathrm{n}^{-1} \sum^{\mathrm{q}}\left(\mathrm{Z}-\mathrm{y}_{\mathrm{i}} / \mathrm{Z}\right)^{\alpha}
$$

Where:

$\mathrm{N}=$ Total number of households

$\mathrm{Z}=$ Poverty line

$\mathrm{y}_{\mathrm{i}}=$ Individual incomes

$\mathrm{q}=$ Number of poor (those with incomes at or below the poverty line, Z)

$\alpha=$ The degree of poverty aversion (sensitivity parameter) When:

$\alpha=0$ gives the incidences of poverty (head count index, or the fraction of the respondents which lives below the poverty line)

$\alpha=1$ gives the depth of poverty, or the amount of income necessary to bring every beneficiary in poverty right up to the poverty line, divided by total population. This can be thought of as the amount that an average person in the economy would have to contribute in order for poverty to be just barely eliminated.

$\alpha=2$ gives the severity of poverty [8]

\section{Results and Discussion}

\subsection{Socio- Demographic Characteristics of the Beneficiaries}

The result of the demographic characteristics in Table 1 shows that majority $(50 \%)$ of the beneficiaries in the study area were 51 - 65 years of age, this shows that youth involvement in rural activities is low. On household size, $44.38 \%$ of the respondents had a family size of between 1 and 10 members and $42.50 \%$ had household size of $11-20$. On education, the result revealed that $55 \%$ of the beneficiaries had non formal education (Quran education) while $45 \%$ had formal education. Response on years of experience shows that $53.75 \%$ of the beneficiaries were experienced farmers with over 25 years of experience in rural activities. The result however shows that $47.50 \%$ of the beneficiaries practiced farming and trade and $37.50 \%$ practiced farming only as means of sustenance. The result demonstrates that the study area is a typical rural setting where agriculture based occupation is the predominant activity among the populace.

\subsection{Perception of the Beneficiaries on Fadama I Project Intervention}

The perceptions of the beneficiaries on Fadama I intervention (Table 2) are presented as follows:

1. The result of the study shows that $98.75 \%$ of the beneficiaries unanimously agreed that the Fadama I interventions had assisted them in meeting up with their farming demands. The respondents further opined that the project had recorded success in addressing the 
farming needs of farming households in the study area. This particular opinion is as claimed by over $80 \%$ of the beneficiaries. They stressed that this had enabled them to purchase the required inputs such as improved variety of seeds, fertilizer, pesticides, etc, for their farming activities.

Table 1. Distribution of the beneficiaries by personal and socio-economic characteristics.

\begin{tabular}{lll}
\hline Variable & Frequency & Percentage \\
\hline Age (Years) & 2 & \\
$20-35$ & 53 & 1.25 \\
$36-50$ & 80 & 33.13 \\
$51-65$ & 25 & 50 \\
66 Above & & 15.63 \\
Household size & 71 & \\
$1-10$ & 68 & 44.38 \\
$11-20$ & 21 & 42.50 \\
21 Above & & 13.13 \\
Education & 88 & \\
Non-formal & 72 & 55.00 \\
Formal & & 45.00 \\
Farming Experience & 2 & \\
$1-10$ & 9 & 1.25 \\
$11-15$ & 36 & 5.63 \\
$16-20$ & 27 & 22.50 \\
$21-25$ & 86 & 16.88 \\
Above 25 & & 53.75 \\
Occupation & 60 & 37.5 \\
Farming Only & 24 & 15 \\
Farming \& Civil Service & 76 & 47.5 \\
Farming \& Trading & & \\
\hline
\end{tabular}

Source: Field work, 2013
1. The result revealed that $87.42 \%$ of Fadama I beneficiaries confided that Fadama I project intervention had increased their income. Moreover, $86.88 \%$ of the beneficiaries also confirmed that the project intervention had improved their standards of living.

2. The beneficiaries $(58.76 \%)$ expressed satisfaction with the approach and monitoring methods adopted by fadama I project in the implementation of the objectives for which it was established. Only $25 \%$ of the beneficiaries indicated a contrary opinion.

3. To cap it up, almost all (93\%) the beneficiaries were unanimous that the intervention had made an appreciable effort at ensuring the participation of farming households in the study area. They further confided that the project's staffs were kind, understanding and tolerant.

4. In line with these perceptions, disclosed that Fadama III beneficiaries have favourable perception towards Fadama farming. According to them, Fadama farming have positive Impact on the productivity of the participants. This may be due to the fact that Fadama participants have more access to agricultural resources and information compared to non-participants [11]. More so, [12] reported similar finding that the officers of the River State Fadama Coordination Office demonstrated committed efforts which ensured effective implementation of rural infrastructure in participated communities.

Table 2. Distribution of respondents' perception on the Fadama I project intervention

\begin{tabular}{|c|c|c|c|c|c|c|c|}
\hline \multirow{2}{*}{$\mathbf{S} / \mathbf{N}$} & \multirow{2}{*}{ Perception question } & \multicolumn{6}{|c|}{ FADAMA I PROJECT } \\
\hline & & SA & A & $\mathbf{U}$ & D & SD & MEAN \\
\hline 1. & Help to meet farm demand. & $86(53.75)$ & $72(45.00)$ & $2(1.25)$ & $0(0.00)$ & $0(0.00)$ & $4.53(0.5255)$ \\
\hline 2. & Improved living standard. & $56(35.00)$ & $99(61.88)$ & $5(3.13)$ & $0(0.00)$ & $0(0.00)$ & $4.32(0.5305)$ \\
\hline 3. & Income increase & $73(45.28)$ & $67(42.14)$ & $20(12.58)$ & $0(0.00)$ & $0(0.00)$ & $4.33(0.6889)$ \\
\hline 4. & Approach used not efficient & $0(0.00)$ & $41(25.63)$ & $25(15.63)$ & $69(43.13)$ & $25(15.63)$ & $2.51(1.0400)$ \\
\hline 5. & Project-officials are kind & $75(46.88)$ & $70(43,75)$ & $17(9.38)$ & $0(0.00)$ & $0(0.00)$ & $4.38(0.6516)$ \\
\hline 6. & Monitoring not efficient. & $1(0.63)$ & $40(25.00)$ & $28(17.50)$ & $49(30.63)$ & $42(26.25)$ & $2.43(1.1472)$ \\
\hline 7. & Project met the farm credit needs & $80(50.00)$ & $72(45.00)$ & $8(5.00)$ & $0(0.00)$ & $0(0.00)$ & $4.45(0.5913)$ \\
\hline
\end{tabular}

Source: Field work, 2013

\subsection{Impact of the Project Intervention on Beneficiaries' Income}

The structure of the household per capita income of the beneficiaries before and after Fadama I project is presented in Table 3 and Table 4. The per capita household income is defined as the total household income divided by the household size. The result revealed that $83.13 \%$ of Fadama I project beneficiaries had a per capita income of $\$ 1,333$ $\mathrm{N} 41,110$, and only $11.25 \%$ earned $\$ 41,111$ - $\$ 80,889$ before Fadama I project intervention. However, after benefitting from Fadama I project support, 85.63\% of the beneficiaries realized a per capita income of $\$ 5,000$ - $\$ 153,278$ and $10.63 \%$ earned $\$ 154,279$ - $\$ 300,556$. The result also revealed that Fadama I project beneficiaries had a mean per capita income of $\$ 28,332.86$ before and $\$ 83,364.47$ after Fadama I project intervention. This finding implies that the beneficiaries had an increases of $\$ 55,031.61$ (194\%) in their mean per capita income after benefiting from Fadama I project support. This finding is in line with [13] who assess the impact of Fadama III on beneficiaries by comparing their income and yield before, and after they became beneficiaries, their research findings revealed that there was a mean difference of $N 224,386.1$ in the income of beneficiaries after becoming members of Fadama III project. 
Table 3. Distribution of Beneficiaries by Mean Per Capita Income Before the Intervention.

\begin{tabular}{|c|c|c|}
\hline Mean per Capita income( $\mathbb{N})$ & Frequency & Percentage \\
\hline $1333-41110$ & 133 & 83.13 \\
\hline $41111-80889$ & 18 & 11.25 \\
\hline $80890-120668$ & 2 & 1.25 \\
\hline $120669-60447$ & 7 & 7.38 \\
\hline $160448-00225$ & 0 & 0.00 \\
\hline $200226-40000$ & 0 & 0.00 \\
\hline MPCHHINC* & N $28,332.86$ & \\
\hline
\end{tabular}

Source: Field work, 2013. *=Mean per capita household income

Table 4. Distribution of Beneficiaries Mean Per Capita Income After the Intervention.

\begin{tabular}{lll}
\hline Mean per Capita income(N) & Frequency & Percentage \\
\hline $5000-153278$ & 137 & 85.63 \\
$155279-300556$ & 17 & 10.63 \\
$300557-455834$ & 4 & 2.50 \\
$455835-606112$ & 2 & 1.25 \\
$\geq 606113$ & 0 & 0.00 \\
MPCHHINC* & $\mathbb{N} 83,364.49$ & \\
\hline
\end{tabular}

Source: Field work, 2013. * = Mean per capita household income

\subsection{Poverty Status of the Beneficiaries' Households}

The poverty situation of the households is discussed under three poverty indicators ie, poverty incidence, poverty depth (gap), and poverty severity. These classifications are in line with the observations of Jenkins and Lambert [9] that every poverty measure should be expressed as a function of the FGT three poverty indicators showing the incidence, the intensity and the inequality among the people. The result of the FGT poverty index is presented in Table 5 .

\subsubsection{Poverty Incidence}

Poverty incidence or poverty rate is the share of the population whose consumption (or income) is below the poverty line. This measure quantifies the share of the population that cannot afford to buy a basket of food [10]. In this respect, the poverty incidence provides an estimate of the number of beneficiaries' households living below the poverty line. The result of the poverty incidences presented in Table 5 shows that $66 \%(0.66)$ of the beneficiaries' households were poor and $34 \%$ were non-poor before the project intervention. After the project intervention, the result shows that $57 \%(0.57)$ were poor while 43 were non poor. The result demonstrate that Fadama I project had decreased the number of poor beneficiaries from $66 \%$ before to $57 \%$ after the project intervention.

\subsubsection{Poverty Depth (Gap)}

This is the average of overall people of the proportionate gap between poor people living standard and the poverty line. Poverty gap measures the degree to which the mean income of the poor differs from established poverty line. According to " reference [10], an advantage of the poverty depth is that it reflects the average shortfall of poor people, thereby giving a better understanding of the depth of poverty and further shows how much would have to be transferred to the poor to bring their expenditure or income up to the poverty line. The result of the FGT index analysis presented in Table 5 shows that the poverty depth for the beneficiaries' households is 32\% (0.32) and 31\% (0.31) before and after Fadama I project intervention, respectively. This finding implies that the beneficiaries' households require a transfer of $32 \%$ and $31 \%$ of their income to be lifted out of poverty before and after the project intervention, respectively.

Table 5. FGT Poverty analysis and interventions impact.

\begin{tabular}{lllllllll}
\hline Before & \multicolumn{3}{c}{ After } & \multicolumn{3}{c}{ Percentage change } \\
\hline $\mathbf{p}_{\mathbf{0}}$ & $\mathbf{p}_{\mathbf{1}}$ & $\mathbf{p}_{\mathbf{2}}$ & $\mathbf{P}_{\mathbf{0}}$ & $\mathbf{P}_{\mathbf{1}}$ & $\mathbf{p}_{\mathbf{2}}$ & $\mathbf{P}_{\mathbf{0}}$ & $\mathbf{P}_{\mathbf{1}}$ & $\mathbf{P}_{\mathbf{2}}$ \\
\hline 0.66 & 0.32 & 0.19 & 0.57 & 0.31 & 0.22 & -13.33 & -1.59 & 11.91 \\
\hline
\end{tabular}

Source: Field work, 2013

\section{Conclusion}

The result demonstrates that the study area is a typical rural setting where agriculture based occupation is the predominant activity among the populace. The finding also shows that Fadama I Project positively impacted on the beneficiaries by increasing their income and improving their living standards. The result found that Fadama I project beneficiaries had increased their mean per capita income from $\$ 28,332.86$ before the project to $\$ 83,364.47$ after the project intervention. In addition, The result revealed that Fadama I project had decreased the number of poor beneficiaries from $66 \%$ before to $57 \%$ after the project intervention. The study recommends that Governments and Development partners need to continue to support agriculture through project interventions such as Fadama I project, but using appropriate strategies that suit the beneficiaries' peculiarities. Appropriate agricultural projects interventions can improve beneficiaries' food security situations and reduce poverty incidences in Nigeria.

\section{References}

[1] National Bureau of Statistics (NBS). (2011). Poverty Profile for Nigeria 2004. NBS Abuja.

[2] Gbola, S. (2012, $13^{\text {th }}$ February). Nigerian poverty level rises, hits 71percent. Nigerian Tribune.

[3] Akinbile, L. A, (2007). Agricultural technology development and Dissemination in Nigeria. Retrieved on $23^{\text {rd }}$ June from www. fPublishers.org

[4] World Bank (1996): Nigeria-Poverty in the Midst of Plenty: the Challenge of Growth with inclusion: Report No. 4.

[5] Olayemi, J. K. (2004). Principles of Micro-economics for Applied Economics Analysis. Mokola-Ibadan, Nigeria: Sico Publishers. 167p.

[6] Food and Agricultural Organisation (FAO) (2007). Food and Agricultural Organisation retreaved on $9^{\text {th }}$, August, 2011 from http/www.virtualcenter.org/enlibrary/a070ieo.pdf

[7] Sokoto State Government (SOSG) (2014). Diary. Sokoto State Government Printing Press, Sokoto. 
[8] Foster, J., Greer, J. and Thorbecke, E. (1984). A Class of Decomposable Poverty Measures. Econometrician, 52: 761766.

[9] Jenkins, S. P. and Lambert, P. J. (1997). Three 'I' s of Poverty Curves, with an Analysis of UK Poverty trends. Oxford Economic Papers, 49: 317-327.

[10] Aguirregabiria, V. (2003). Decomposable Poverty Measures, Encyclopaedia of world Poverty. Availableat: http://people.bu.edu/vaguirre/wpapers/decomposable_encyclo pedia.pdf Last assessed 25/07/2013.

[11] Apata, O. M. and Saliu, O. J. (2016). Impact Assessment of
Fadama Project on Agricultural Development in Kwara State, Nigeria, American Journal of Experimental;griculture, 10 (4): 1-7.

[12] Chukuemeka, R. A., Dennis, N. H., Nyekachi N. A. and Emeka, N. (2019). Evaluation of National Fadama III Development Project: Catalysm For Rural Development in Rivers State, Nigeria, Busecon Review of Social Sciences, Vol 1 (1).

[13] Kuza Y., Okwoche V. A. and Age A. I. (2018). Assessment of the impact of fadama III Development project on Beneficiaries in Nasarawa State. Greener Journal of Agricultural Science, Vol 8 (9): 197-202. 